\title{
Pengembangan LKPD berbasis PBL untuk Meningkatkan Kemampuan Pemecahan Masalah Siswa Kelas VIII pada Materi Sistem Persamaan Linear Dua Variabel
}

\author{
Aflahul Ma'wa ${ }^{1^{*}}$, Hapipi ${ }^{2}$, Muhammad Turmuzi ${ }^{2}$, Syahrul Azmi ${ }^{2}$ \\ ${ }^{1}$ Mahasiswa Pendidikan Matematika, FKIP, Universitas Mataram, Mataram \\ ${ }^{2}$ Dosen Pendidikan Matematika, FKIP, Universitas Mataram, Mataram \\ aflahmw43@gmail.com
}

Diterima: 16-12-2021; Direvisi: 30-12-2021; Dipublikasi: 30-12-2021

\begin{abstract}
The purpose of this study was to develop student worksheets based on PBL (Problem Based Learning) to improve the problem-solving abilities of class VIII students at MTs Hikmatusysyarief NW Salut Narmada for the 2020-2021 school year on two-variable linear equation systems. PBL-based LKPD (Problem Based Learning) is an LKPD that is arranged based on the phases of the PBL learning model. The development of this product aims to overcome the weaknesses in the teaching and learning process and overcome the weaknesses of students' problem-solving abilities. The research methodology used in developing PBL-based LKPD is 4D (Define, Design, Development, and Dissemination). Data collection techniques using interview guidelines and questionnaires. The result of the research is a product in the form of LKPD based on PBL (Problem Based Learning) on the material of a two-variable linear equation system. The product has been declared valid with very good criteria by two validators. Based on the results of a limited trial on the use of the developed product, it is known that the PBL-based LKPD can improve the problem-solving ability of class VIII students of MTs Hikmatusysyarief NW Salut Narmada.
\end{abstract}

Keywords: student worksheet; problem based learning; problem solving ability.

\begin{abstract}
Abstrak
Tujuan penelitian ini adalah untuk mengembangkan lembar kerja peserta didik berbasis PBL (Problem Based Learning) untuk meningkatkan kemampuan pemecahan masalah siswa kelas VIII MTs Hikmatusysyarief NW Salut Narmada tahun pelajaran 2020-2021 pada materi sistem persamaan linear dua variabel. LKPD berbasis PBL (Problem Based Learning) merupakan LKPD yang disusun berdasarkan fasefase pada model pembelajaran PBL. Pengembangan produk ini bertujuan untuk mengatasi kelemahankelemahan pada proses belajar mengajar dan mengatasi kelemahan kemampuan pemecahan masalah peserta didik. Metodologi penelitian yang digunakan dalam mengembangkan LKPD berbasis PBL adalah 4D (Define, Design, Development, dan Dissemination). Teknik pengumpulan data menggunakan pedoman wawancara dan kuisioner. Hasil penelitian adalah produk berupa LKPD berbasis PBL (Problem Based Learning) pada materi sistem persamaan linear dua variabel. Produk telah dinyatakan valid dengan kriteria sangat baik oleh dua orang validator. Berdasarkan hasil uji coba terbatas terhadap penggunaan produk yang dikembangkan, diketahui bahwa LKPD berbasis PBL dapat meningkatkan kemampuan pemecahan masalah peserta didik kelas VIII MTs Hikmatusysyarief NW Salut Narmada.
\end{abstract}

Kata Kunci: lembar kerja peserta didik; problem based learning; kemampuan pemecahan masalah. 


\section{PENDAHULUAN}

Pada Kurikulum 2013 yang diberlakukan di Indonesia, di mana konsep dasar K13 menurut Musfiqon (2016:8) tetap berbasis kompetensi. Kurikulum berbasis kompetensi dirancang untuk memberikan pengalaman belajar seluas-luasnya bagi siswa dalam mengembangkan kemampuan untuk bersikap, berpengetahuan, berketerampilan, dan bertindak. Dalam K13 model pembelajaran yang digunakan adalah model pembelajaran inquiry, model pembelajaran berbasis masalah, dan model pembelajaran berbasis proyek (Musfiqon, 2016:10). Berdasarkan Permendikbud Nomor 22 Tahun 2016 terdapat beberapa prinsip pembelajaran kurikulum 2013, diantaranya adalah pembelajaran yang berpusat pada peserta didik (students centered), pembelajaran berbasis aneka sumber belajar, dan pembelajaran berbasis proses untuk penguatan pendekatan ilmiah, serta sangat disarankan menggunakan pendekatan pembelajaran yang menghasilkan karya berbasis masalah (Problem Based Learning).

Berdasarkan observasi yang dilakukan selama melaksanakan Program Pengalaman Lapangan (PPL) di MTs Hikmatusysyarief NW Salut Narmada pada tahun 2019 lalu, diketahui bahwa guru di sana melaksanakan pembelajaran matematika dengan menjelaskan materi yang ada di buku paket dari dinas pendidikan. Biasanya dalam proses belajar mengajar guru hanya mengarahkan siswa mencatat materi yang ada di buku paket, kemudian menjelaskan materi yang dibahas dan diakhir pembelajaran guru memberikan tugas yang ada pada bagian akhir dari buku paket tersebut, sehingga biasanya peserta didik yang diberikan tugas dibagian akhir seperti ini malas untuk mengerjakannya karena jenuh atau bosan.

Berdasarkan hasil wawancara yang dilakukan pada bulan Desember 2020 dengan salah satu guru matematika di MTs Hikmatusysyarief NW Salut Narmada serta dengan pengamatan hasil belajar peserta didik kelas VIII yang terdiri dari lima kelas, didapatkan informasi bahwa terdapat beberapa peserta didik dengan hasil belajar matematika yang masih di bawah nilai 70 atau nilai KKM, dengan rendahnya kemampuan pemecahan matematis yang dimiliki. Pada jawaban peserta didik pada salah satu soal Ulangan semester ganjil T.P 2020-2021, terlihat bahwa terdapat beberapa indikator yang tidak dapat dicapai oleh peserta didik. Di antaranya indikator merancang strategi penyelesaian, melaksanakan strategi penyelesaian, serta menyimpulkan dan memeriksa kembali jawaban yang diperoleh.

Permasalahan mengenai rendahnya hasil belajar dan rendahnya kemampuan pemecahan masalah matematis peserta didik ini perlu dicarikan solusi. Cara yang dilakukan adalah dengan melaksanakan perbaikan pada proses pembelajaran. Salah satu penentu keberhasilan proses pembelajaran dan keberhasilan dalam pencapaian tujuan pembelajaran matematika adalah perangkat pembelajaran. Perangkat pembelajaran merupakan sekumpulan alat atau komponen yang digunakan dalam proses pembelajaran yang terdiri dari silabus, RPP, bahan ajar, dan tes hasil belajar. Satu dari bahan ajar cetak yang digunakan dalam proses pembelajaran di sekolah adalah LKPD (Zulfah dkk, 2018: 34-35). 
Lembar Kerja Peserta Didik (LKPD) adalah lembaran-lembaran berisi materi, ringkasan, dan tugas yang harus dikerjakan oleh peserta didik. Peran LKPD dalam pembelajaran salah satunya adalah sebagai bahan ajar yang bisa meminimalkan peran pendidik namun lebih mengaktifkan peserta didik (Anggraini dkk, 2016:351). LKPD yang disusun dapat dirancang dan dikembangkan sesuai dengan kondisi dan situasi kegiatan pembelajaran yang akan dihadapi (Rohaeti dkk, 2009:2).

Agar tercapainya tujuan pembelajaran matematika yang salah satunya adalah kemampuan pemecahan masalah matematis, maka perlu diberikan inovasi baru terhadap LKPD yang bertujuan untuk mengkonstruksi pengetahuan peserta didik. Inovasi yang dilakukan pada LKPD tersebut yaitu berupa penggunaan suatu model atau strategi pembelajaran yang dijadikan sebagai landasan dalam mengembangkan LKPD. LKPD akan semakin optimal jika berlandaskan pada salah satu model atau strategi pembelajaran yang memiliki tujuan untuk meningkatkan kemampuan pemecahan masalah peserta didik dan mengajarkan cara menyelesaikan sebuah permasalahan. Salah satu model atau strategi pembelajaran yang dapat digunakan untuk mencapai tujuan tersebut adalah melalui PBL (Zulfah dkk, 2018:35-36). Menurut Polya (dalam Lismaya, 2019:15), model yang digunakan dalam pembelajaran matematika dan sangat penting dalam menumbuhkan kemampuan matematis adalah model PBL.

Problem Based Learning (PBL) adalah suatu strategi atau model pembelajaran ataupun pendekatan pembelajaran yang menggunakan masalah dunia nyata sebagai suatu konteks atau masalah bagi peserta didik untuk belajar tentang cara berpikir kritis dan keterampilan pemecahan masalah, serta dapat memperoleh pengetahuan dan konsep yang esensial dari materi pelajaran. Jika biasanya proses pembelajaran diawali dengan pemberian materi pelajaran dan barulah dilanjutkan dengan pemberian masalah, maka pembelajaran dengan PBL menjadikan pemberian permasalahan sebagai awal dari proses pembelajaran (Zulfah, 2017:5).

Kurniawati (2017:10) mengungkapkan bahwa perangkat pembelajaran atau bahan ajar yang berbasis Problem Based Learning yang dikembangkan dapat meningkatkan penguasaan klasikal, karena Problem Based Learning mengarahkan sepenuhnya kegiatan pada peserta didik seperti melakukan pengamatan pada objek nyata untuk dapat menjawab pertanyaan yang telah diungkapkan pada awal kegiatan pembelajaran. Hal ini didukung dengan pernyataan Paidi (2011:197) bahwa masalah kompleks yang ada dalam LKPD sangat potensial untuk melatih kemampuan peserta didik dalam memecahkan masalah autentik dan menemukan alternatif solusinya.

Berdasarkan uraian di atas, maka penelitian dengan judul Pengembangan LKPD Berbasis PBL untuk Meningkatkan Kemampuan Pemecahan Masalah Siswa Kelas VIII MTs Hikmatusysyarief NW Salut Narmada Tahun Pelajaran 2020/2021 pada Materi Sistem Persamaan Linear Dua Variabel penting untuk dilakukan. 


\section{METODE PENELITIAN}

Pengembangan LKPD berbasis PBL (Problem Based Learning) bertujuan untuk menghasilkan produk LKPD yang disajikan dan disusun berdasarkan sintak-sintak model pembelajaran PBL (Problem Based Learning) yang dapat meningkatkan kemampuan pemecahan masalah peserta didik. Oleh karena itu, penelitian ini merupakan penelitian dan pengembangan (Research and Development) yang bertujuan untuk menghasilkan produk. Dan menguji keefektifan produk (Sugiyono, 2012:297). Akker (1999:3-6) mengatakan bahwa penelitian pengembangan biasanya dilakukan untuk mengembangkan kurikulum, media dan teknologi, belajar dan pembelajaran, serta pendidikan guru dan didaktik. Penelitian ini dilaksanakan di MTs Hikmatusysyarief NW Salut Narmada dimulai sejak bulan Agustus 2019 sampai dengan bulan Mei 2021.

Subjek uji coba terbatas dalam penelitian ini adalah peserta didik kelas VIII MTs Hikmatusysyarief NW Salut Narmada Lombok Barat. Instrumen yang digunakan adalah pedoman wawancara untuk guru dan angket untuk validasi produk. Interview (wawancara) merupakan alat pengumpul informasi dengan cara mengajukan sejumlah pertanyaan secara lisan untuk dijawab secara lisan pula (Hadi dkk, 1998:135). Pada penelitian ini, wawancara dilakukan untuk menganalisis kebutuhan terhadap LKPD berbasis Problem Based Learning (PBL). Adapun Kuisioner (angket) merupakan suatu alat pengumpul informasi dengan cara menyampaikan sejumlah pertanyaan tertulis untuk dijawab secara tertulis pula oleh responden (Hadi dkk, 1998:137).. Uji validitas yang digunakan adalah validitas ahli dengan bantuan 2 orang ahli dalam hal ini 1 dosen pendidikan matematika FKIP Unram dan 1 guru matematika MTs Hikmatusysyarief NW Salut Narmada sebagai validator.

Prosedur pengembangan LKPD berbasis PBL, mencakup beberapa langkah pengembangan berdasarkan tahap 4D (Define, Design, Develop, Dissemination).

Data yang diperoleh dalam penelitian ini dibagi menjadi dua, yaitu data kualitatif dan data kuantitatif. Data kualitatif berupa kritik dan saran yang telah diberikan oleh para ahli sebagai validator produk yang dikembangkan. Sedangkan data kuantitatif berupa skor yang diberikan dalam penilaian produk LKPD oleh ahli pada lembar validasi produk.

Menurut Turmuzi (2016:69), mengkonversi data kuantitatif ke kualitatif dapat dilakukan dengan acuan pada Tabel 1 berikut:

Tabel 1. Konversi Data Kuantitatif ke Data Kualitatif Skala Lima

\begin{tabular}{cc}
\hline Indeks Validitas & Kategori \\
\hline$X>X i+1,80 S b i$ & Sangat Valid \\
$X i+0,60 S b i<X \leq X i+1,80 S b i$ & Valid \\
$X i-0,60 S b i<X \leq X i+0,60 S b i$ & Cukup Valid \\
$X i-1,80 S b i<X \leq X i-0,60 S b i$ & Kurang Valid \\
$X \leq X i-1,80 S b i$ & Tidak Valid \\
\hline
\end{tabular}

Keterangan: 
Rerata ideal $(X i): \frac{1}{2}$ (skor maksimum ideal + skor minimum ideal)

Simpangan baku ideal (Sbi): $\frac{1}{6}$ (skor maksimum ideal - skor minimum ideal).

Selanjutnya, produk yang sudah diuji kevalidannya, diuji coba secara terbatas pada salah satu sekolah, yaitu MTs Hikmatusysyarief NW Salut Narmada. Uji coba produk secara terbatas ini dilakukan untuk mengetahui pengaruh produk yang telah dikembangkan, apakah dapat membantu meningkatkan kemampuan pemecahan masalah peserta didik atau tidak.

\section{HASIL DAN PEMBAHASAN}

\subsection{Tahap Define (Pendefinisian)}

Berikut Pada tahap ini, dilakukan beberapa persiapan sebelum merancang produk. Persiapan ini terdiri dari analisis ujung depan, analisis siswa, analisis konsep, analisis tugas dan perumusan tujuan pembelajaran.

Berdasarkan hasil wawancara di MTs Hikmatusysyarief NW Salut Narmada, diketahui bahwa pelaksanaan pembelajaran matematika belum menerapkan model pembelajaran yang sesuai dengan kurikulum 2013. Model pembelajaran yang sering diterapkan saat ini adalah model pembelajaran langsung dengan metode ceramah. Hal ini menyebabkan guru maupun siswa kesulitan dalam melaksanakan pembelajaran berbasis pendekatan saintifik.

Bahan ajar yang digunakan guru berupa buku paket kurang dapat mendukung penerapan model pembelajaran berbasis masalah (PBL). Peserta didik terbiasa menggunakan buku paket untuk menghafalkan rumus yang telah disediakan dan mengerjakan latihan yang disediakan. Akibatnya, peran peserta didik sebagai pemecah masalah matematis sesuai dengan pendekatan saintifik, tidak dapat terlaksana. Sehingga dibutuhkan media pembelajaran yang dapat mengatasi masalah-masalah tersebut.

Berdasarkan hasil observasi selama pelaksanaan PPL dan hasil wawancara dengan guru matematika serta pengamatan hasil belajar di MTs Hikmatusysyarief NW Salut Narmada, diketahui bahwa peserta didik memiliki kemampuan yang cukup baik dalam memahami penjelasan yang diberikan oleh guru, meskipun terdapat beberapa peserta didik dengan hasil belajar yang masih di bawah nilai KKM, serta masih terdapat peserta didik yang kurang memperhatikan penjelasan guru dengan melakukan hal lain di luar pembelajaran.

Salah satu kompetensi dasar yang harus dicapai peserta didik SMP/MTs kelas VIII pada mata pelajaran matematika adalah peserta didik dapat membuat dan menyelesaikan model matematika dari masalah nyata yang berkaitan dengan sistem persamaan linear dua variabel. Untuk dapat mencapai kompetensi dasar tersebut, terdapat beberapa hal yang harus dipahami peserta didik yakni memahami definisi dan unsur-unsur yang 
terdapat pada sistem persamaan linear. Sehingga diperlukan media yang dapat membantu peserta didik untuk memahaminya.

Tugas yang diberikan pada peserta didik untuk dapat memahami materi yang akan disajikan pada produk, disusun berdasarkan fase-fase dalam penerapan model pembelajaran PBL. Fase pertama, peserta didik ditugaskan untuk membaca dan memahami permasalahan materi SPLDV. Fase kedua, peserta didik ditugaskan untuk menyelesaikan permasalahan secara berkelompok, dan berdiskusi dengan anggota kelompok. Fase ketiga, peserta didik ditugaskan untuk memahami langkah-langkah penyelesaian masalah SPLDV dan menyelesaikan permasalahan tentang materi SPLDV. Fase keempat, peserta didik ditugaskan untuk mempresentasikan hasil penyelesaian. Fase kelima, peserta didik ditugaskan untuk melakukan refleksi terhadap kegiatan pembelajaran yang telah dilakukan.

Adapun rumusan tujuan pembelajaran yang akan dicapai, sebagai acuan pengembangan produk adalah, peserta didik dapat menentukan nilai variabel SPLDV, peserta didik dapat membuat model matematika dari masalah nyata yang berkaitan dengan SPLDV, dan Peserta didik dapat menyelesaikan permasalahan nyata yang berkaitan dengan materi SPLDV.

\subsection{Tahap Design (Perancangan)}

Berdasarkan tahap define, media yang dipilih untuk menghasilkan produk adalah LKPD. Format penyajian isi LKPD didasarkan pada fase-fase penerapan model pembelajaran PBL (Problem Based Learning). Rancangan awal produk yang mewakili setiap fase dalam penerapan model pembelajaran PBL dapat dilihat pada Tabel 2.

Tabel 2. Rancangan LKPD berbasis PBL (Problem Based Learning)

\begin{tabular}{ll}
\hline \multicolumn{1}{c}{ Fase } & \multicolumn{1}{c}{ Representasi pada LKPD } \\
\hline $\begin{array}{l}\text { Orientasi siswa pada } \\
\text { masalah }\end{array}$ & $\begin{array}{l}\text { Mengenalkan dan menarik perhatian peserta didik pada } \\
\text { masalah dengan menyajikan masalah dalam bentuk } \\
\text { cerita dengan konteks yang dekat dengan keseharian } \\
\text { peserta didik (kontekstual). }\end{array}$ \\
$\begin{array}{l}\text { Mengorganisasikan siswa } \\
\text { untuk belajar }\end{array}$ & $\begin{array}{l}\text { Mengorganisasikan peserta didik dengan } \\
\text { menginformasikan kepada peserta didik bahwa LKPD } \\
\text { akan dikerjakan secara berkelompok dan mengarahkan } \\
\text { peserta didik untuk berdiskusi dengan anggota kelompok. }\end{array}$ \\
$\begin{array}{l}\text { Membimbing penyelidikan } \\
\text { individual maupun kelompok }\end{array}$ & $\begin{array}{l}\text { Menuntun peserta didik menyelesaikan masalah dengan } \\
\text { memberikan langkah-langkah penyelesaian masalah } \\
\text { SPLDV serta memberikan ruang yang cukup untuk } \\
\text { peserta didik dalam menyelesaikan masalah. }\end{array}$ \\
$\begin{array}{l}\text { Mengembangkan dan } \\
\text { menyajikan hasil karya }\end{array}$ & $\begin{array}{l}\text { Menginstruksikan kepada masing-masing kelompok } \\
\text { untuk menempelkan hasil penyelesaian di papan tulis } \\
\text { dan menunjuk perwakilan kelompok untuk } \\
\text { mempresentasikannya secara bergantian. }\end{array}$ \\
$\begin{array}{l}\text { Menganalisis dan } \\
\text { mengevaluasi proses } \\
\text { pemecahan masalah }\end{array}$ & $\begin{array}{l}\text { Meminta peserta didik untuk memberikan catatan } \\
\text { terhadap proses pembelajaran. }\end{array}$ \\
\hline
\end{tabular}




\subsection{Tahap Development (Pengembangan)}

Rancangan produk pada tahap design, dikembangkan menjadi LKPD berbasis PBL (Problem Based Learning), kemudian divalidasi, direvisi, dan diuji coba secara terbatas di MTs Hikmatusysyarief NW Salut Narmada.

LKPD berbasis PBL (Problem Based Learning) pada materi SPLDV, divalidasi oleh 2 orang validator yang terdiri dari satu orang dosen Program Studi Pendidikan Matematika Fakultas Keguruan dan Ilmu Pendidikan Universitas Mataram yakni Ibu Nilza Humaira S, M.Pd, dan satu orang guru pengampu mata pelajaran matematika kelas VIII di MTs Hikmatusysyarief NW Salut Narmada yakni Ibu Kiki Alfiyah L, S.Pd. Data hasil validasi ahli terhadap LKPD berbasis PBL pada materi SPLDV dapat dilihat pada Tabel 3.

\begin{tabular}{|c|c|c|c|c|c|}
\hline \multirow{2}{*}{ No } & \multirow{2}{*}{ Aspek } & \multicolumn{2}{|c|}{$\Sigma$ Skor } & \multicolumn{2}{|c|}{ Kriteria } \\
\hline & & Validator 1 & Validator 2 & Validator 1 & Validator 2 \\
\hline 1. & Penyajian & 37 & 39 & Sangat Baik & Sangat Baik \\
\hline 2. & Isi & 5 & 5 & Sangat Baik & Sangat Baik \\
\hline 3. & Bahasa & 9 & 10 & Sangat Baik & Sangat Baik \\
\hline 4. & Tampilan & 8 & 9 & Baik & Sangat Baik \\
\hline \multicolumn{2}{|c|}{ Total } & 59 & 63 & & \\
\hline \multicolumn{2}{|c|}{ Rata-rata } & 4,54 & 4,84 & Sangat Baik & Sangat Baik \\
\hline \multicolumn{2}{|c|}{$\begin{array}{l}\text { Rata-rata } \\
\text { Keseluruhan }\end{array}$} & 4,69 & & Sangat Baik & \\
\hline
\end{tabular}

Secara keseluruhan, Tabel 3 menunjukkan bahwa hasil validasi produk yang dikembangkan berdasarkan penilaian kedua validator adalah sangat baik. Ditinjau dari segi penyajian, isi, bahasa maupun tampilan dari produk yang dikembangkan, produk tersebut memenuhi kriteria sangat baik. LKPD berbasis PBL (Problem Based Learning), selain dikembangkan berdasarkan pada fase model PBL (Problem Based Learning), juga memperhatikan syarat-syarat yang harus dipenuhi dalam penyusunan LKPD sebagai media pembelajaran, yakni syarat didaktik, syarat konstruksi dan syarat teknis. Menurut Salirawati (2019:2-3), syarat didaktik mengatur tentang penggunaan LKPD yang bersifat universal, artinya dapat digunakan peserta didik dengan kemampuan yang berbeda-beda. Syarat konstruksi adalah syarat-syarat yang berkenaan dengan penggunaan bahasa, susunan kalimat, kosa kata, tingkat kesukaran dan kejelasan petunjuk. Adapun syarat teknis adalah syarat yang menekankan pada aspek penyajian LKPD yang berupa tulisan, gambar, dan tampilan.

Terdapat beberapa saran yang diberikan validator ahli terhadap produk yang dikembangkan. Saran dari kedua validator yang digunakan sebagai acuan revisi produk disajikan pada Tabel 4. 
Tabel 4. Saran Validator sebagai Acuan Revisi Produk

\begin{tabular}{cl}
\hline \multicolumn{1}{c}{ Validator } & \multicolumn{1}{c}{ Saran } \\
\hline Validator 1 & $\begin{array}{l}\text { Hilangkan hari/tanggal pada halaman depan dan perbaiki } \\
\text { urutan pada langkah pemecahan masalah. }\end{array}$ \\
Validator 2 & $\begin{array}{l}\text { Gunakan warna yang muda untuk background, agar tulisan } \\
\text { bisa terbaca jelas. }\end{array}$
\end{tabular}

Tahap uji coba terbatas dilakukan untuk mengetahui apakah LKPD berbasis PBL (Problem Based Learning) dapat meningkatkan kemampuan pemecahan masalah peserta didik kelas VIII MTs Hikmatusysyarief NW Salu Narmada tahun ajaran 2020-2021 pada materi SPLDV.

Tahap uji coba terbatas ini dilakukan terhadap 18 peserta didik kelas VIII di MTs Hikmatusysyarief NW Salut Narmada, yang dipilih berdasarkan pertimbangan guru pengampu mata pelajaran matematika. Data skor kemampuan pemecahan masalah peserta didik sebelum penggunaan LKPD yang dikembangkan diperoleh dari hasil pengamatan jawaban ulangan tengah semester dan dikuatkan dengan hasil pengamatan guru pengampu mata pelajaran matematika kelas VIII. Pengamatan jawaban ulangan tengah semester dilakukan dengan memperhatikan strategi penyelesaian peserta didik, dan dihubungkan dengan indikator kemampuan pemecahan masalah. Adapun sebagian besar peserta didik menjawab soal dengan tidak menuliskan langkah awal penyelesaian, akibatnya pada tengah penyelesaian peserta didik sering keliru dalam menuliskan angka, operasi hitung, dan lain sebagainya.

Pada tahap ini, 18 peserta didik secara berkelompok telah mengerjakan LKPD berbasis PBL materi SPLDV pada metode penyelesaian yang berbeda. Terdapat 6 kelompok yang terbentuk, dengan anggota masing-masing kelompok terdiri dari 3 peserta didik dengan kemampuan yang berbeda-beda. 2 kelompok mengerjakan LKPD dengan metode eliminasi, 2 kelompok mengerjakan LKPD dengan metode substitusi, dan 2 kelompok mengerjakan LKPD dengan metode gabungan.

Setelah melalui semua aktifitas pembelajaran yang sesuai dengan LKPD berbasis PBL pada materi SPLDV, selanjutnya peserta didik diukur kemampuan pemecahan masalah matematikanya dengan diberikan soal pemecahan masalah yang dikerjakan secara individual. Berikut disajikan Tabel 5 yang menunjukkan hasil perbandingan skor kemampuan pemecahan masalah 18 peserta didik sebelum dan sesudah digunakannya LKPD berbasis PBL pada materi SPLDV.

Tabel 5. Data Rekapitulasi Skor Kemampuan Pemecahan Masalah

\begin{tabular}{lllll}
\hline No & Aspek Penilaian & $\begin{array}{c}\text { Rata-rata } \\
\text { skor Awal } \\
\text { KPM }\end{array}$ & $\begin{array}{c}\text { Rata-rata } \\
\text { skor Akhir } \\
\text { KPM }\end{array}$ & Peningkatan \\
\hline 1. & $\begin{array}{l}\text { Kemampuan pemecahan } \\
\text { masalah }\end{array}$ & 4,8 & 6,7 & 1,9 \\
\hline
\end{tabular}


Berdasarkan Tabel 4.7 rekapitulasi skor kemampuan pemecahan masalah di atas, dapat dinyatakan bahwa skor kemampuan pemecahan masalah peserta didik setelah penggunaan LKPD berbasis PBL pada materi SPLDV mengalami peningkatan. Di mana rata-rata skor kemampuan pemecahan masalah sebelum penggunaan LKPD berbasis PBL adalah 4,8. Sedangkan rata-rata skor kemampuan pemecahan masalah setelah penggunaan LKPD berbasis PBL adalah 6,7. Dengan total peningkatan adalah 1,9. Hal ini sejalan dengan hasil penelitian Imran (2017) terhadap penggunaan LKPD berbasis PBL yang menyebutkan bahwa efektifitas LKPD dinilai baik dalam meningkatkan kemampuan pemecahan masalah.

\subsection{Tahap Dissemination (Penyebaran)}

Penyebarluasan produk LKPD berbasis PBL (Problem Based Learning) dilaksanakan di MTs Hikmatusysyarief NW Salut Narmada. sehingga guru matematika di MTs Hikmatusysyarief NW Salut Narmada dapat menggunakannya dalam pembelajaran matematika kelas VIII pada materi sistem persamaan linear dua variabel (SPLDV). LKPD berbasis PBL pada materi SPLDV diserahkan kepada guru pengampu mata pelajaran matematika dalam bentuk soft file.

\section{SIMPULAN}

Berdasarkan hasil penelitian pada tahap validasi produk, dapat disimpulkan bahwa produk yang dikembangkan telah memenuhi kriteria sangat baik dan dapat dikatakan valid. Adapun skor rata-rata validasi produk dari kedua validator adalah 4,69 dengan kategori sangat baik. Kemudian, berdasarkan hasil penelitian pada tahap uji coba terbatas, dapat disimpulkan bahwa produk yang dikembangkan dapat meningkatkan kemampuan pemecahan masalah peserta didik. Adapun skor rata-rata kemampuan pemecahan masalah peserta didik sebelum dan sesudah menggunakan produk adalah 4,8 dan 6,7.

\section{REKOMENDASI}

Berdasarkan penelitian dan pengembangan LKPD berbasis PBL (Problem Based Learning), dapat dikemukakan beberapa saran sebagai berikut:

1. Bagi peserta didik, diharapkan peserta didik dapat lebih fokus dalam kegiatan pembelajaran, baik dengan menggunakan produk yang telah dikembangkan, maupun dalam pembelajaran yang belum menggunakannya.

2. Bagi guru, diharapkan guru matematika dapat memanfaatkan produk yang telah dikembangkan dalam proses pembelajaran matematika, menyebarluaskan produk kepada guru matematika lainnya, serta dapat membuat produk-produk yang sejenis.

3. Bagi peneliti, hasil penelitian ini dapat dikembangkan untuk materi-materi matematika lainnya, ataupun mata pelajaran lain, serta dapat diuji efektivitasnya ataupun pengaruhnya terhadap suatu faktor. 


\section{REFERENSI}

Akker, J.V.D. (1999). Principles and Method Of Development Research (EDS). Design Approaches and Tools in Education and Training. Dordrecht: Kluwer Academic Publisher.

Anggraini, Rivalia, dkk. (2016). Pengembangan Lembar Kerja Siswa (LKS) Berbasis Keterampilan Proses Di SMAN 4 Jember. Jurnal Pembelajaran Fisika. Vol. 4(4): 350356.

Das. Salirawati. Penyusunan dan Kegunaan LKS Dalam Proses Pembelajaran. (staff.uny.ac.id/sites/default/.../das-salirawati.../19penyusunan-dan-penggunaanlks.pdf), 20 Januari 2019.

Hadi, Amirul \& Haryono. (1998). Metodologi Penelitian Pendidikan. Bandung: CV Pustaka Setia.

Imran, dkk. (2018). Prosiding Seminar Nasional Biologi dan Pembelajarannya. Pengembangan LKPD Berbasisl Model PBL untuk Sisswa kelas X MIPA SMA/MA. hal. 275-280.

Kurniawati dkk. (2017). Pengembangan Perangkat Pembelajaran Berbasis Problem Based Learning (PBL) Pada Materi Pelajaran Biologi Materi Klasifikasi Tumbuhan Untuk Meningkatkan Kompetensi Siswa Kelas X SMA Taman Harapan Malang. (http://karyailmiah.um.ac.id/index.php/biologi/article/view/40917. Diakses tanggal 12 juni 2018).

Lismaya, Lilis. (2019). Berpikir Kritis \& PBL (Problem Based Learning). Surabaya: Media Sahabat Cendekia.

Musfiqon. (2016). Penilaian Otentik Dalam Pembelajaran Kurikulum 2013. Sidoarjo: Nizamia Learning Center.

Paidi. (2011). Pengembangan Perangkat Pembelajaran Biologi Berbasis Masalah. Jurnal Pendidikan. Vol. 41(2): 185-201.

Permendikbud Nomor 22 Tahun 2016 Tentang Standar Proses.

Rohaeti, Eli, dkk. (2009). Pengembangan Lembar Kerja Siswa (LKS) Mata Pelajaran Sains Kimia Untuk SMP. Inovasi Pendidikan. Vol. 10(1): 1-11.

Sugiyono. (2012). Metode Penelitian Kuantitatif, Kualitatif dan R\&D. Bandung: alfabeta.

Turmuzi, Muhammad. (2016). Evaluasi Proses Dan Hasil Belajar Matematika. Mataram: Universiatas Mataram.

Zulfah. (2017). Tahap Preliminary Research Pengembangan LKPD Berbasis PBL Untuk Materi Matematika Semester 1 Kelas VIII SMP. Jurnal Pendidikan Matematika. Vol. 1(2): 1-12.

Zulfah, dkk. (2018). Pengembangan Lembar Kerja Peserta Didik Berbasis Problem Based Learning Untuk Materi Matematika Kelas VIII. Jurnal Pendidikan Matematika. Vol. 12(2): $33-46$. 